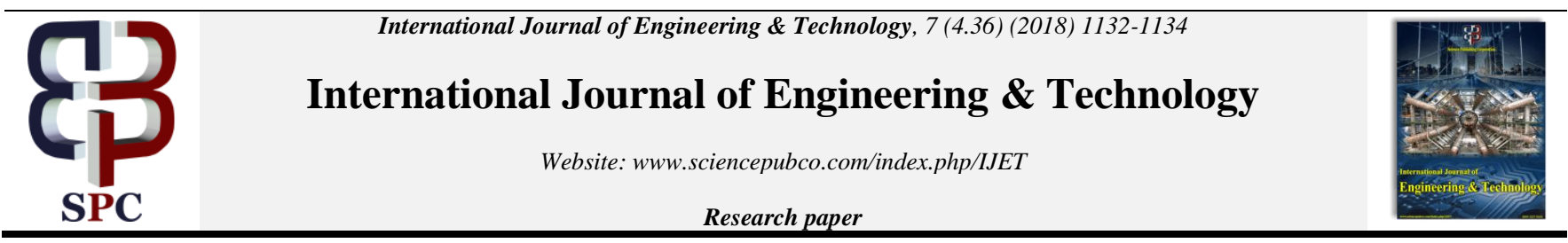

\title{
Estimation of Intellectual Capital in the Sphere of Inclusive Education by the Example of University
}

\author{
Yu.B. Nadtochiy, L.S. Budovich \\ MIREA - Russian Technological University, Moscow, Russia
}

\begin{abstract}
The present article discusses the stages of a comprehensive assessment of the intellectual capital of a teacher in an educational organization in an inclusive education. The analysis of student survey data on the assessment of the teacher's intellectual capital is presented. A comparison of the essence of concept and structure of intellectual capital in domestic and foreign scientific research has been carried out. Along with this, the authors propose and substantiate the criteria for evaluating the intellectual capital of an educational organization of higher education as a whole, based on the results of which it is possible to determine key areas for further development of the educational institution's activities.
\end{abstract}

Keywords: inclusive education intellectual capital; valuation of intellectual capital; the university.

\section{Introduction}

The concept of "intellectual capital" is becoming increasingly popular in the modern world. Many foreign and domestic works are devoted to the study of intellectual capital. Answers to the question of "what is intellectual capital?" show a wide range of opinions regarding the definition of this concept. And there is still no clear opinion about what is meant by intellectual capital - each author has his own approach to understanding this definition.

Intellectual capital can be viewed as a combination of knowledge, skills, and professional results obtained on their basis (for example, for a teacher, these are articles, teaching aids, educational and methodical complexes of subjects taught, research projects, etc.).

The evaluation of the intellectual capital of a university is, first of all, the evaluation of the intellectual capital of all its employees.

\section{Research method}

\subsection{The essence and structure of intellectual capital in domestic and foreign studies}

ntellectual activity, human knowledge, intellectual abilities, intellectual potential, intangible assets, intellectual property this is a small list of terms that are closely related (and sometimes replacing, being synonymous) with the concept of "intellectual capital" [1-3, 11-14].

At present, it is possible to note the presence of various approaches to the definition of the concept "intellectual capital", and accordingly, to the definition of its structure (components) and evaluation methods in foreign and domestic studies. Due to the fact that there are a lot of works devoted to the issues of intellectual capital, we will dwell on some of them that are of the greatest interest (Table 1).

Table 1: Definition of the essence of the concept and structure of intellectual capital in domestic and foreign studies

\begin{tabular}{|c|c|}
\hline Definition & Structure (composition) \\
\hline \multicolumn{2}{|r|}{ Foreign studies } \\
\hline $\begin{array}{l}\text { Intellectual capital is the sum of knowledge of all employees of } \\
\text { the company, ensuring its competitiveness. This is an intellectual } \\
\text { material that includes knowledge, experience, information and } \\
\text { intellectual property and is involved in the creation of values [4, p. } \\
11-12] .\end{array}$ & $\begin{array}{l}\text { Considered by T. Stewart according to the scheme of Hubert St. Onge and Leif } \\
\text { Edvinsson. Human capital (located in the heads of the company's employees). } \\
\text { Structural capital (located in the structures of the company). } \\
\text { Consumer capital (located in consumers). } \\
\text { Intellectual capital is created as a result of the interaction of these types of capital. }\end{array}$ \\
\hline $\begin{array}{l}\text { Intellectual capital consists of stock and movement useful for the } \\
\text { organization of knowledge }[5, \text { p. 64]. }\end{array}$ & 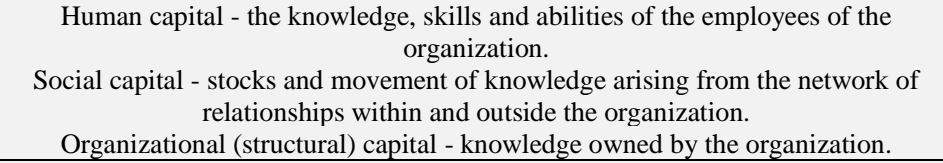 \\
\hline $\begin{array}{l}\text { Intellectual capital is the roots of the organization, the hidden } \\
\text { conditions of development that lurk behind the visible facade of } \\
\text { its buildings and product range [6, p. 434]. }\end{array}$ & $\begin{array}{c}\text { Human capital is a body of knowledge, practical skills, and creative abilities of the } \\
\text { organization's personnel. } \\
\text { Structural capital is all that allows employees of the organization to realize their } \\
\text { production potential. }\end{array}$ \\
\hline $\begin{array}{l}\text { Intellectual capital is a term used to refer to intangible assets, } \\
\text { without which a company cannot exist in the modern world [7,p. }\end{array}$ & $\begin{array}{l}\text { Market assets are intangible assets associated with market transactions. Intellectual } \\
\text { property as an asset (intellectual assets) is property that is acquired as a result of }\end{array}$ \\
\hline
\end{tabular}




\begin{tabular}{|c|c|}
\hline 30]. & $\begin{array}{l}\text { mental activity and is protected by law. } \\
\text { Human assets are a set of collective knowledge of the organization's employees, } \\
\text { their creative abilities, problem solving skills, leadership skills, entrepreneurial and } \\
\text { managerial skills. } \\
\text { Infrastructure assets - technologies, methods, and processes that make an } \\
\text { organization's work possible at all; they form an environment in which employees of } \\
\text { the organization work and communicate with each other. }\end{array}$ \\
\hline $\begin{array}{l}\text { Intellectual capital (knowledge) is all that has value for an } \\
\text { organization and is contained in people working in it or arises } \\
\text { from production processes, systems or organizational culture [8, } \mathrm{p} \text {. } \\
\text { 3]. }\end{array}$ & $\begin{array}{l}\text { Knowledge and skills of specific people, norms and value systems, databases, } \\
\text { methodologies, software, industrial experience (know-how), licenses, brands, trade } \\
\text { secrets, etc. }\end{array}$ \\
\hline \multicolumn{2}{|r|}{ Domestic research } \\
\hline $\begin{array}{l}\text { The intellectual capital of a subject is the value of the aggregate of } \\
\text { its intellectual assets, including intellectual property, its natural } \\
\text { and acquired intellectual abilities and skills, as well as its } \\
\text { accumulated knowledge bases and useful relationships with other } \\
\text { subjects [9, p. 101]. }\end{array}$ & $\begin{array}{l}\text { An integral part of intellectual capital is intellectual property (can be isolated, } \\
\text { transferred to other persons, evaluated and practically used) and intellectual abilities } \\
\text { (real and potential capabilities of individuals or an organized group of people } \\
\text { capable of performing certain complex works or operations). }\end{array}$ \\
\hline $\begin{array}{c}\text { Intellectual capital (individual intellectual capital or intellectual } \\
\text { capital of an individual) is a type of capital that includes the } \\
\text { intellect of a social subject (person, group of people, organization, } \\
\text { society) and the products of its activity - information and } \\
\text { knowledge that have novelty, have socio-economic value and } \\
\text { ensure it income (benefit) and competitive advantages [10,p. } \\
\text { eight]. }\end{array}$ & $\begin{array}{l}\text { ndividual human intelligence, inseparable from its carrier, characterized by certain } \\
\text { properties, level of development and is the basis of capital. } \\
\text { Intellectual achievements of a person, which are of practical use and have a certain } \\
\text { value both for him and for other social subjects. (Intellect is understood as a set of } \\
\text { cognitive and creative abilities of a social subject). }\end{array}$ \\
\hline
\end{tabular}

Based on the study of various opinions about essence of the concept under consideration, it can be concluded that the intellectual capital of an organization is capital with the following characteristics:

- provides a competitive advantage to the organization;

- provides the holder with a higher income, subject to investment in it;

- requires from the organization and from the person high costs in its development and formation;

- is constantly accumulating (knowledge, skills, abilities, experience);

- not amenable to a full assessment (difficult to measure).

\section{Results and analysis}

The authors have developed a comprehensive assessment of the intellectual capital of a teacher in the field of inclusive education for universities, which includes the following steps:

zero stage - goals and objectives of the assessment;

the first stage is the teacher's self-assessment;

second stage - expert assessment;

the third stage - evaluation by the consumer and customer of the educational service;

fourth stage - the results of a comprehensive assessment and recommendations.

Let us consider in more detail the stage of evaluation of the teacher's intellectual capital by students.

In order to study the opinions of students about the possibilities of evaluating their teacher's intellectual capital, a survey was conducted. It was attended by 103 students of $1-4$ courses of Moscow Technological University (now RTU MIREA), students in the following areas: "Innovation", "Management", "Optotehnika" and "Biotechnical systems and technologies" (bachelor degree, full-time education). The respondents were asked the following questions: By what criteria and indicators can you personally assess the teacher's intellectual capital? By what criteria and indicators will your parents be able to assess the teacher's intellectual capital?

The majority of survey participants $(65 \%)$ believe that the teacher's intellectual capital can be assessed by the way he conducts classes (lecture, practical, laboratory and other classes) and preference is given to classes with interesting material, the presence of interesting practical tasks, and they also appreciate the opportunity "Live" communication with the teacher, taking into account the respect for students. This is also a motivator for students to study. In the course of the survey conducted earlier
[11], it was revealed that the students basically consider interesting, necessary material and the implementation of practical tasks - the motivation necessary for them to attend classes at an educational institution.

During personal conversations, many expressed the opinion that a degree, academic title, teacher's position for students is not important and not interesting, they don't pay attention to it (and many don't even know what position and what rank / degree is higher).

The survey results show that basically a wide range of opinions has turned out. Students often offered to assess the teacher's intellectual capital based on their idea of the ideal teacher: someone pays attention to the teacher's age (prefers young teachers), someone to the presence of humor (teacher's ability to joke, defuse the situation with a joke in the classroom). They offered to look at the experience of a teacher in a different field of activity, not only scientific and pedagogical.

There is a proposal to evaluate the following parameters:

- the ability to teach material in an accessible language (without reading from a sheet, using presentations, etc.);

- the quantity and quality of scientific work of the teacher;

- education and experience;

- the ability to quickly switch from one information to another when discussing;

- the ability to cite historical references, examples from life; - personal communication with the teacher (his personal qualities); - interests and hobbies of the teacher in his spare time.

Summarizing the data obtained, it can be concluded that at stage 3 (evaluation of intellectual capital by consumers and customers), students for evaluating the teacher's intellectual capital should be offered an evaluation sheet using a five-grade grade scale, which lists assessment points, for example:

1) for the lesson (lecture and practical): the content of the lesson, the availability of the presentation of the material, the level of answers to questions, the use of pedagogical innovations, the use of feedback, literate speech, the use of good examples, modern cases, equipment, etc ;

2) for control measures (exam, test, defense of coursework, etc.): the complexity of passing the discipline, the questions for the preparation correspond to the material presented at the lectures and practical classes, consultations for students, etc.

Also, consumer capital is assessed according to the commitment of consumers (customers) of your organization and resistance to competitors, measured by customer satisfaction and is associated with improved financial performance of the organization [12]. For an educational organization of higher education, this may manifest 
itself in the number of applicants who enroll based on positive feedback from students.

\section{Conclusion}

Based on the above mentioned statements, the authors proposed criteria and indicators for evaluating intellectual capital in the field of inclusive education for universities.

The complex of indicators for assessing the intellectual capital of a university is evaluation of the three components of intellectual capital: human, organizational and communication (relational) capital.

1. The main element of intellectual capital is human capital. The evaluation criteria in this case may be the attractiveness of the educational organization, as well as the effectiveness of the faculty.

2. Organizational capital. The assessment criteria in this case may be the level of innovation and scientific development of the educational organization, as well as the level of development of educational activities.

3. Communication capital. The assessment criteria in this case can be the dynamics of the formation of the brand of the educational organization, as well as the dynamics of the expansion of external relations.

After the evaluation of the intellectual capital of the educational organization, it seems appropriate to determine the key directions for the development of the university's activities:

1) improving the competitiveness of the educational organization in the education market;

2) increasing the prestige of the educational organization as a whole, contributing to attracting and retaining more students with high potential;

3 ) increasing the efficiency of the faculty;

4) innovative development of the university;

5) the scientific development of the educational organization;

6) successful development of educational activities;

7) the formation of a brand of educational organization and its promotion on the educational market, as well as the expansion of external relations and international cooperation.

\section{References}

[1] Galbraith D.K. New industrial society. Favorites. M .: Eksmo, 2008. (In Russian).

[2] Nonaka I., Takeuchi H. The company is the creator of knowledge. The origin and development of innovation in Japanese firms: Per. from English A. Traktinsky. M .: ZAO Olimp-Business, 2011. (In Russian).

[3] NadtochiyYu.B., Budovich L.S. Intellectual capital of the organization: the essence, structure, approaches to evaluation // Russian Technological Journal, 2018. V. 6, No. 2, P. 82-95.

[4] Stuart, T.A. Intellectual capital. New source of wealth organizations: Per. from English V.A. Nostrino. M .: Generation, 2007. (In Russian).

[5] Armstrong M. The practice of human resource management. $\mathrm{SPb}$.: Peter, 2004. (In Russian).

[6] Edwinsson L., Malone M. Intellectual capital. Determination of the true value of the company // New post-industrial wave in the West. Anthology / subd. V.L. Inozemtsev. M .: Academia, 1999. p. 429 447. (In Russian).

[7] Brookings E. Intellectual capital: Per. from English / Ed. L.N Kovalik. SPb .: Peter, 2001. (InRussian).

[8] Bukovich U., Williams R. Knowledge Management: A Guide to Action: Per. from English M .: INFRA-M, 2002. (In Russian).

[9] Leontyev BB The price of intelligence. Intellectual capital in the Russian business. M .: Publishing Center "Shareholder", 2002. (In Russian).

[10] Dresvyannikov V.A., Loseva O.V. Human intellectual capital theory, methodology and valuation practice: monograph. $\mathrm{M}$. RUSAINS, 2017. (In Russian).
[11] Zerniy Yu.V., Nadtochy Yu.B. Problems of modern technical education in Russia // Economics and Entrepreneurship. 2016. № 9 (74). P. 435-443. (In Russian).

[12] The official website of Sweiby / Mode of access: http://www.sveiby.com/ (contact date 26.04.2018).

[13] Nazarenko M.A., Khronusova T.V. Big Data in Modern Higher Education. Benefits and Criticism // International Conference "Quality Management, Transport and Information Security, Information Technologies", IT and QM and IS, 2017, 8085914, p. 676-679.

[14] Kudzh S.A., Kochetkova L.N., Nazarenko M.A. The philosophy of quality management // Russian Technological Journal, 2015. 3 (8), P. 1-8. (In Russian). 